\title{
PORT READINESS IN FACING GLOBALIZATION: INDONESIAN CASE STUDY*
}

\author{
Melda Kamil Ariadno, Arie Afriansyah, Yetty Komalasari Dewi* ${ }^{*}$
}

** Lecturers at the Faculty of Law, Universitas Indonesia.

Article Info

Received : 12 June 2014 | Received in revised form : 29 October 2014 | Accepted : 10 December 2014

Corresponding author's e-mail : meldakamil@gmail.com.

\begin{abstract}
International trade cannot be separated from the role of international shipping. More than $80 \%$ of goods transported through sea from a region to another, from one Country to another Country. Since the dawn of the voyage, port cannot be separated from the voyage itself. Adequate port will ensure good international shipping. Increasing number of international shipping also means increasing volume of international trade. With a variety of factors such as geographical factor, natural resources, and population, Indonesia should be a key player in international trade by sea. However, the reality is still far from ideal, especially when compared with neighboring countries. This research aims to map the condition and situation of ports in Indonesia, especially in the legal field so that can be known what things that can be recommended to optimize the role of Indonesian ports in international trade by sea.
\end{abstract}

Keywords: Ports, Globalization, ISPS, International Trade

\begin{abstract}
Abstrak
Perdagangan internasional tidak dapat dilepaskan dari peranan pelayaran internasional. Lebih dari 80\% barang-barang dibawa melalui laut dari satu daerah ke daerah lain, dari satu Negara ke Negara lain dan satu benua ke benua lainnya. Sebagaimana telah berlangsung sejak awal pelayaran lahir di dunia, pelabuhan tidak dapat dipisahkan dari pelayaran itu sendiri. Pelabuhan yang memadai akan menjamin berlangsungnya pelayaran internasional yang baik. Dengan meningkatnya pelayaran internasional berarti meningkat juga volume perdagangan internasional. Dengan berbagai faktor keuntungan seperti faktor geografis, sumber daya alam, jumlah penduduk, sudah seharusnya Indonesia menjadi pemain kunci (key player) dalam perdagangan internasional melalui jalur laut. Akan tetapi, kenyataan masih jauh dari harapan yang ideal terutama jika dibandingkan dengan Negara-negara tetangga. Riset ini bertujuan untuk memetakan kondisi dan situasi pelabuhan Indonesia khususnya di bidang hukum sehingga dapat diketahui hal-hal apa saja yang dapat direkomendasikan untuk mengoptimalkan peran pelabuhan-pelabuhan Indonesia dalam perdagangan internasional melalui laut.
\end{abstract}

Kata kunci: Pelabuhan, Globalisasi, ISPS, Perdagangan Internasional

\section{Introduction}

International trade cannot be separated from the role of international shipping. More than $80 \%$ of goods transported through sea from a region to another region, from one Country to another Country, and from one Continent to another Continent. ${ }^{1}$

* This article is taken from the research conducted by the authors with the full funding from the Directorate Research and Community Engagement of Universitas Indonesia in 2013.

${ }^{1}$ See Alexandros M. Goulielmos and Agisilaos A. Anastasakos, "Worldwide Security Measures for Shipping, Seafarers and Ports: An Impact Assessment of ISPS code" (2005) 14(4) Disaster Prevention and 
Indonesia which has a vast territory especially the area of the sea, and supported by fifth highest number of population in the world, naturally can contribute more in international trade. As a producer, Indonesia has many natural resources and service product which can be offered to the world. Besides, high number of productive manpower can make Indonesia as an effective producer Country. As a marketing area, high number of population in Indonesia also makes Indonesia as an excellent market for products and services from both domestic and outside of Indonesia.

As an archipelagic state, Indonesia has interest in international shipping line, especially for keeping territorial security and intensifies cooperation in field of maritime security in the context of international trade smoothness. In addition to being the host of the Strait of Malacca and three of Indonesian archipelagic sea lanes (Alur Laut Kepulauan Indonesia - ALKI), Indonesia also has interests in terms of exports and imports of goods by sea.

However, in fact, Indonesia is still not optimally utilizing its role in international trade by sea. Until now, Indonesia has not been significantly used as a transit and/ or main destination of international shipping. Singapore is a major transit port for international sea lane trough South East Asia. With all the comparisons of the potential resources between Indonesia and Singapore, actually Indonesia could contribute more than current situation international shipping.

Ports $^{2}$ in Indonesia have low competitiveness value. According to the Global Competitiveness Index 2011 issued by the World Economic Forum, from twelve of the assessment parameters, "seaport and infrastructure" obtains the second lowest value after "technological readiness" parameter in Indonesia. The brilliance of Indonesia's macroeconomic growth is said to be "the most improved countries in the G-20" and Indonesia assessed overall ranks of $44^{\text {th }}$ from 139 countries. This rank is much different with the condition of seaport that just being in position $82^{\text {th }}$ of $139 .^{3}$ Therefore, this paper concludes that the Indonesian seaports need serious treatment of the Port Authority and other related parties, so that ports in Indonesia ready to face the globalization of international trade.

This paper will highlight how Indonesia plans its legal policy in an attempt to revitalize the role of ports in Indonesia so that contribute more in international trade by sea. For such purpose, this paper will discuss the situation and the role of the Indonesian port in general, followed by regulation mapping for the port both nationally and internationally. It is intended to be able to see whether the rule of law have been sufficient to support the existence of ports as international ports.

\section{Role of Ports Indonesia in General}

Indonesia has 141 international ports, but only 6 were certified by the government which considered having the appropriate eligibility as international ports, namely: the port of Belawan, port of Dumai, the port of Panjang, Tanjung Priok port, Tanjung Emas port and the Tanjung Perak port. Indonesia's international trade activities, such

\footnotetext{
Management 462 - 478.

${ }^{2}$ See Carsten Fink et. al., "Trade in International Maritime Services: How Much Does Policy Matter?" (2002) 16(1) World Bank Economic Review 81.

${ }^{3}$ T. Geiger, Indonesia's Competitiveness: Sustaining the Growth Momentum. Jenewa: World Economic Forum, 2011).
} 
as export-import activities, can only be done at the port that has been certified. ${ }^{4}$

For international shipping, Indonesia's rank declined drastically from rank 44th in 2007 become rank 80th in $2010 .^{5}$ This raises the question as Indonesia has sought to increase its commitment to conform to international standards. As an example, Indonesia by Presidential Decree Number 65 of 1980 ratified International Convention for the Safety of Life at Sea/SOLAS of $1974 .{ }^{6}$ This was followed up in 2003, with with the issuance of Decree of Ministry of Transportation of the Republic of Indonesia (SK Menteri Perhubungan) Number 33 of 2003 on the Application of Amendments to SOLAS 1974 on the International Ships and Port Facility Security (ISPS Code) ${ }^{7}$ in the Indonesian region. ISPS Code $^{8}$ formally applied as from July $1,2004 .{ }^{9}$

Although the port obviously has a very important role in the national economy, Indonesia does not have a port system with good performance in terms of the users. ${ }^{10}$ Indonesia's main port terminal, the Jakarta International Container Terminal (JITC), has been known as one of the most inefficient main terminal in Southeast Asia, in terms of productivity and unit costs. ${ }^{11}$ However, JICT still one of the better performing Indonesian ports. Performance indicators for all major commercial ports suggest the entire port system is very inefficient and very urgent need of upgrading. Data on occupancy levels mooring ships, the average time to prepare the way home (turn-around) and working time as a percentage of turnaround time is under the international standards and indicate that ships spend too much time at berth or to queue outside the port.

The Law No. 18 Year 2008 on Shipping (Shipping Law of 2008) provides the foundational reform of the port system in Indonesia as a whole. The most obvious is that the law removes state-sector monopoly on ports and opens new opportunities for private sector participation. This can lead to the entry of competition in the port sector, which can provide pressure to reduce prices and generally improve the service of the port. However, the transformation of Indonesian port system is a long and difficult process. Shipping Law of 2008 is very important and is a positive first step, but much remains to be done with regards to the development of supporting institutions, regulations and planning documents. Until regulational and institutional

${ }^{4}$ Henricus W. Ismanthono, Kamus Istilah Ekonomi dan Bisnis (Terms Dictionary of Economic and Business), (Jakarta: Kompas, 2012), p. 164.

${ }^{5}$ Complete research available at http://www.ekon.go.id/media/filemanager/2012/04/17/b/a/ bab_ii_perkembangan_rev.pdf (last accessed November 6, 2012)

${ }^{6}$ Known as "SOLASConvention".Official fulltextavailableathttp://seafarers.msa.gov.cn/InternationalPact/InternationalFile/SOLAS/SOLAS\%201974\%20 consolidated\%20edition2004/\%E8\%8B\%B1\%20 SOLAS\%20 consolidated\%20edition2004\%20.pdf (last accessed November 4 2012, 15.04 Western Indonesia Time)

7 Official full text available at http://www.portofantwerp.com/sites/portofantwerp/files/ISPS code_en.pdf (last accessed November 4 2012, 15.16 Western Indonesia Time)

${ }^{8}$ ISPS Code is a guideline that governs about sercurity of ship and port facility for ratified member States. By ratifying ISPS Code, Indonesia is a subject of all of provisions contained in ISPS Code. It means that Indonesia must ensure complicance of the ship and port facility according to standards set by ISPS Code.

9 “ISPS Code Resmi Diterapkan (ISPS Code Officially Applied)." Full article available at http://www. bumn.go.id/20635/publikasi /berita/isps-code-resmi-diterapkan/ (last accessed November 42012 ).

${ }^{10}$ According to Global Competitiviness Report (GCR) of 2006, ranking of "Indonesian Ports Infrastructure Quality" positioned in rank 98 of 121 countries surveyed and fell 5 ranks since the year 2001. Note that the GCR is influenced by the perceptions of business owners.

${ }^{11}$ David Ray, "Reformasi Sektor Pelabuhan Indonesia dan UU Pelayaran Tahun 2008 (Indonesian Port Sector Reform and Shipping Law of 2008)", USAID Research Paper (2008), p. 6. 
framework available, investors face a policy vacuum and do not know exactly what processes should be followed and what approvals and permits must be obtained and from which institution.

\section{A. Governance, Structure, and Institution}

Indonesian port system organized into a hierarchical system consisting of about 1700 port. There are 111 ports, including 25 main strategic ports, which considered as commercial ports and managed by four state-owned enterprises, Perum Pelabuhan Indonesia I, II, III, and IV (Pelindo) with geographical coverage described in Table 1 below. In addition, there are also 614 ports some of them managed by Technical Implementation Unit (Unit Pelaksana Teknis/UPT), or non-commercial ports which tend to be profitable and just have slight strategic value.

Currently, PT Pelabuhan Indonesia (Pelindo) enjoys monopoly on the main commercial ports legislated and regulatory authority over private sector ports. In almost all major ports, Pelindo acts both as an operator and a single port authority, dominating the main provision of port services as listed below:

a. Harbor waters (including backfill channel and basin) for the movement of vessel traffic, anchoring, and mooring.

b. Sailing and towage (tugs).

c. Port facilities for loading and unloading activities, animal handling, warehouse and container yard; conventional terminals, container and bulk; passenger terminal.

d. Electricity, clean water supply, waste disposal, and telephone service to ship.

e. Land for office space and industrial area.

f. Medical training center and harbor.

Table 1. Pelindo: Geographical Coverage

\begin{tabular}{|c|l|l|}
\hline $\begin{array}{c}\text { Perum } \\
\text { Pelabuhan }\end{array}$ & \multicolumn{1}{|c|}{ Coverage (Province) } & \multicolumn{1}{c|}{ Governed Ports } \\
\hline Pelindo I & Aceh, Sumatera Utara, Riau & $\begin{array}{l}\text { Belawan, Pekanbaru, Dumai, Tanjung Pinang, } \\
\text { Lhokseumawe }\end{array}$ \\
\hline Pelindo II & $\begin{array}{l}\text { Sumatera Barat, Jambi, Sumatera } \\
\text { Selatan, Bengkulu, Lampung, Jakarta }\end{array}$ & $\begin{array}{l}\text { Tanjung Priok, } \\
\text { Panjang, Palembang, Teluk Bayur, Pontianak, } \\
\text { Cirebon, Jambi, Bengkulu, Banten, Sunda Kelapa, } \\
\text { Pangkal Balam, Tanjung Pandan }\end{array}$ \\
\hline Pelindo III & $\begin{array}{l}\text { Kelatan, Nusa Tenggara Barat, Nusa } \\
\text { Tenggara Timur (sebelumnya Timor } \\
\text { Timur) }\end{array}$ & $\begin{array}{l}\text { Tanjung Perak, Tanjung Emas, Banjarmasin, } \\
\text { Benoa, Tenau/Kupan }\end{array}$ \\
\hline Pelindo IV & $\begin{array}{l}\text { Sulawesi (S,SE,Tengah dan Utara), } \\
\text { Maluku, Irian Jaya }\end{array}$ & $\begin{array}{l}\text { Makassar, Balikpapan, Samarinda, Bitung, Ambon, } \\
\text { Sorong, Biak, Jayapura }\end{array}$ \\
\hline
\end{tabular}

Institutional regarding port experienced many changes, most recently with the 
enactment of Shipping Law of 2008, replacement of old Law No. 21 Year 1992 on Shippping and Government Regulation No. 61 of 2009 concerning Port substitute old Government Regulation No. 69 of 2001 concerning Port. There is a fundamental change in the institutional aspects of port management, namely the separation between the functions of the regulator (regulation) the operator function (operation), including the separation of the functions of policy-making and operational functions of management and control of the environment in the port area in Indonesia.

For institutional ports in Indonesia with the enactment of Shipping Law of 2008, and Government Regulation No. 61 Year 2009 concerning Port, have made a separation between the Port Authority as a regulator and PT Pelindo (Persero), Port Business Entity and Port Operator Unit (Unit Penyelenggara Pelabuhan/UPP) as the terminal operator in the port in Indonesia. Special to the Port of Tanjung Priok has formed Tanjung Priok Port Authority (Otoritas Pelabuhan Tanjung Priok) in accordance with the Ministrial Decree No. PM 63/2010 on the Organization and Administration of the Office PelabuhanTanjung Priok Port Authority, so it has separation of regulator and operator functions in the Port of Tanjung Priok. Regulatory function is done by the Tanjung Priok Port Authority and PT Pelindo II (Persero) serves only as an operator of the terminal.

The essence of Shipping Law of 2008 is to abolish monopolies, providing greater opportunities to the state-owned enterprises (BUMN), local government owned enterprises (BUMD), and privately owned port business entity to make business in the port. This law also gives a very open opportunities for businesses to work together to build a port that is maintained existence, productivity and service quality services. It means that, every business actors in accordance with the role, function and line of business have the same opportunity to do business in the port, in accordance with applicable regulations. ${ }^{12}$

\section{Regulation Concerning Ports}

As explained previously, port sector plays an important role in the sustainability of international trade. The importance of the port promotes the regulation of port parameters that can be recognized as an international port under the international law, even if the law of the port itself is essentialy governed by national law. ${ }^{13}$ Various International organization whose scope of work are related with international shipping such as International Maritime Organization, also consider that the port is an important part which need to be regulated specifically for the safety and security of international shipping. Further explanation of the international conventions rlated to the port will be described below:

12 Ibid.

${ }^{13}$ In contrast to maritime law, law more ports exist under national law as though the function of ports around the world can be said to be approximately similar to each other, the condition of each port are diverse and thus require specific settings for each port. United Nations Conference on Trade and Development, Legal Aspects of Port Management, available at .... In addition, the regulation of the port is also based on national law as the port itself is part of a State as an internal water which is set in Article 8 of the United Nations Convention on the Law of the Sea, 1982, in which is located in full sovereignty. 


\section{A. International Regulations in Port Sector}

\section{Geneva Convention and Statute on the International Régime of Maritime Ports 1923}

Geneva Convention and Statute on the International Régime of Maritime Ports (Geneva Convention 1923) concluded on December 9, 1923 became the starting point of the regulation of maritime ports used in international shipping. Geneva Convention in 1923 is divided into two parts, namely the Convention governing administrative matters concerning the enforceability of the Statute which consists of 24 chapters as an integrated part of the Convention, as well as things like ratification and accession, while the Statute regulates the function of maritime ports.

Statute provides a definition of maritime ports as all the usual ports visited by ships and used for foreign trade. ${ }^{14}$ In the use of maritime ports, there is an obligation of the State to enforce the principle of equality of treatment for each ship, either ship of another Contracting State or not, as the ship of the State itself in the area of maritime ports are located in under the sovereignty of the State. ${ }^{15}$ The principle of equality of treatment is realized in the form of freedom to access to ports, the use of the port, full use of the benefits associated with navigation and commercial activities were granted to the ship, cargo and passengers inside. ${ }^{16}$ With the implementation of the principle of equal treatment, all facilities related to cruise ships such as the division of mooring, loading and unloading facilities, as well as dues and charges for everything that bears the name of or for the benefit of the state, public officials, licensees or any activity should also be enjoyed by all ships. ${ }^{17}$

However, the application of the principle of equal treatment does not restrict the freedom of the port authority to take any action deemed necessary for the proper activity of the port, where the actions taken in line with the principle of equal treatment as referred to in Article 2 of the Statute. ${ }^{18}$ It can also be seen as a form of protection against user port itself, so that the principle of equality of treatment can still be applied appropriately. To achieve these objectives, Article 4 of the Statute provides that dues and charges levied for port operations and port-related bylaw or regulation to be published before they are applied. ${ }^{19}$

Contracting State has the authority to assign customs duties in any maritime port in the territory of the State, where the amount specified in the port should not be different from any other port in the territory of that State unless there are special reasons such as geographical conditions, economic, or technical issues that are specific to the port. ${ }^{20}$ Although there are special conditions on a port, Contracting

${ }^{14}$ Loose translation from “...which are normally frequented by sea-going vessels and used for foreign trade..." League of Nations, Geneva Convention and Statute on the International Régime of Maritime Ports 1923, Art. 1. Statute on the International Régime of Maritime Ports 1923 is not applied to maritime coasting trade (Art. 9); warships or other ships which bears politional or administrative function, or other ship which currently used exclusively by Navy, military, or air force of a State (Art.13); and fishing vessel along with its catch (Art. 14).

${ }^{15}$ Ibid., Art. 2, par. 1.

${ }^{16}$ Ibid.

${ }^{17}$ Ibid., par. 2.

${ }^{18}$ Ibid., Art. 3.

${ }^{19}$ Ibid., Art. 4, par. 1-2.

${ }^{20}$ Ibid., Art. 7, par. 1. 
State get special customs facilities on the other route that is used to import or export of goods, with a special note, these conditions can not be used as a form of discrimination against the export or import activities that take place in the territory of that State. ${ }^{21}$

Contracting State has the authority to suspend the benefits gained by the following ship cargo and passengers from the application of the principle of equal treatment in the territory of the Country, after giving notice through diplomatic channels. ${ }^{22}$ In addition, the Contracting State also has the right to make arrangements for a berth, ${ }^{23}$ as well as organize and manage tug services as deemed appropriate by the port. ${ }^{24}$ In case Contracting State bound by an agreement that gives special rights to another State within a certain area in the port area for the purposes of facilitating the transit of goods or passengers from or to the State, the enforceability of the agreement which then gives special rights can not rule out making another Contracting State validity of this Statute. ${ }^{25}$

\section{Convention on Facilitation of International Maritime Traffic 1965}

Convention on Facilitation of International Maritime Traffic 1965 (known as the FAL Convention), motivated by a petition by members of the International Chamber of Commerce for an regulation related with the facilitation of the international shipping traffic, the members of ICC which are the international maritime transport users faced difficulties in trade by sea and needed an efficient facilitation in that field. ${ }^{26}$ The member states of the Intergovernmental Maritime Consultative Organization (IMCO) responded by forming a Group of Experts to prepare a convention on the facilitation of shipping traffic, followed by the holding of the Conference on Facilitation of Maritime Travel and Transport in London, March 29 until 9 April 1965. ${ }^{27}$ Conference was attended by 57 Member States and to discuss the draft convention and its annex which has been prepared by the Group of Experts, which is largely accepted both of the structure and formulation of the said convention. ${ }^{28}$

FAL Convention consists of 16 Articles which mainly regulate about the aims of the Convention, ${ }^{29}$ responsibility of the contracting parties, and procedure to amending international standard aloong with recommended practice to contracting parties as comprehensively described in the Annex. Annex itself regulate matters related to:

${ }^{21}$ Ibid., par. 2.

${ }^{22}$ Ibid., Art. 8, par. 1.

${ }^{23}$ Ibid., Art. 10

${ }^{24}$ Ibid., Art. 11

${ }^{25}$ Ibid., Art. 15, par. 1.

${ }^{26}$ The members of the International Chamber of Commerce published a brochure that outlines their concerns in the use of maritime transport and appealed to the Intergovernmental Maritime Consultative Organization (IMCO) to undertake the necessary action to remedy the situation. Jochen Erler, "The New Convention on Facilitation of International Maritime Traffic", McGill Law Journal, vol. 13, no. 2, p. 324.

${ }^{27}$ Ibid., p. 325.

${ }^{28}$ Ibid.,

${ }^{29}$ Aims of FAL Convention is to facilitate international maritime traffic by reducing administrative work, simplifying bureaucracy, service and document procedure related to arrival, docking, and departure of ships that carry out international shipping. Portius, Draft Chapter on Port Regulations for the IAPH Introduction to Maritime Law for Port Officials, p. 7. 
- $\quad$ Required documents for both departure and arrival of persons or cargo;

- Measure for granting permission for cargo, passengers, crew, and baggage;

- Public health and quarantine, including sanitary measure for plants and animal, and;

- $\quad$ Port services

FAL Convention stipulates that the Contracting Governments are obliged to adopt any standards to facilitate and speed up the international shipping traffic and to prevent unnecessary delays to ships and people and goods onboard.$^{30}$ Contracting Governments are also obliged to cooperate in preparing and applying any guidelines to facilitate the arrival, overnight stay, and departure of ships either from coastal states or non-coastal state in accordance with this Convention and its Annex. ${ }^{31}$ For the purposes of the application of the FAL Convention and its Annex, the following definitions should be noted:

- "Standards" is defined as anything that is used as a criterion for application of uniform rules in accordance with the Convention, where it is deemed necessary and practical in order to facilitate international maritime traffic; ${ }^{32}$

- "Recommended Practices" are all things that used as a criterion for the measures taken in accordance with the wishes of the Government Contracting in order to facilitate international maritime traffic. ${ }^{33}$

Provisions related to the port mostly regulated in Annex, which begins with defining terminology ports as "ports, terminals, offshore terminal, ship and repair yard or roadstead which is normally used to load, unload, repair and anchoring ship, or any place another where boats can dock". ${ }^{34}$ In meeting the objectives of the conclusion of the FAL Convention, the provision in the Annex related to the port performance is more focused in provision about service in port. Some service-related standards in the port stated as follows:

- Contracting Government shall adopt any measure that can be used to manage common services implemented by public authorities at the port in order to avoid the suspension of the ship after ship's arrival and before departure, as well as reducing the time to as low as possible to complete all the formality, in which for the purpose of the public authority must obtain sufficient information about the estimated time of arrival or departure of the ship; ${ }^{35}$

- Basicly, all the activities in the form of a medical test or other additional tests, either bacterial or other test should not be charged by health authorities carried out day or night, if such action is required to ensure the health of the person being tested, also not for the benefit of visit and inspection of ships for the sake of quarantine except for ship inspection

${ }^{30}$ Convention on Facilitation of Maritime Traffic, signed on 9 April 1965, Art. 1.

${ }^{31}$ Exception of the said provision applied to warship or yacht. Ibid., Art. 2.

${ }^{32}$ Loose translation from "...those measures the uniform application of which by Contracting Governments in accordance with the Convention is necessary and practicable in order to facilitate international maritime traffic." Ibid., Art. 6.

${ }^{33}$ Loose translation from "...those measures the application of which by Contracting Government is desirable in order to facilitate international maritime traffic." Ibid.

${ }^{34}$ Annex of Convention on Facilitation of Maritime Traffic 1966 Section 1 - Definitions and general provisions.

${ }^{35}$ Annex of Convention on Facilitation of Maritime Traffic 1966 Section 7 - Miscellaneous provisions, 7.3. 
for the issuance of a Deratting or Deratting Exemption Certificate, health authorities should not charge person for every vaccination for people who come by ship also for related certificates. However, if criterion other than the measure of its previous criterion is a necessary part associated with the ship or its passengers or crew and charges imposed upon them by the health authorities, the fee shall be charged in accordance with a uniform rate for the relevant area and should be charged without differentiating nationality, domicile or residence of any person concerned or for nationality, flag, registration or ownership of the ship; ${ }^{36}$ and

- When the volume of traffic on port allows, public authorities should ensure that services are provided to meet the formality associated with cargo and baggage, regardless of value or type. ${ }^{37}$

In addition to some of the standards that have been described, there are some recommended practices related to the service at the port as follows:

- Regular services by public authorities in the port should be done without charge during normal working hours. Public authority itself must establish normal working hours for their activities in the port that is consistent with the usual period for substantial workload. ${ }^{38}$

- When the services of public authorities held outside of regular working hours as stipulated in point 7.2 of Annex, these activities should be carried out with appropriate conditions and should not exceed the costs incurred for these activities; ${ }^{39}$ and

- Contracting Government should take a measure to make a regulation where the Government will allow another Government to obtain certain facilities before or during the shipping to inspect the ship, passengers, crew, baggage, cargo, as well as documentation for the purposes of customs, immigration, public health, and animal and plant quarantine if such action would facilitate the licensing to permit on arrival in the territory of the Government intended by the ship. ${ }^{40}$

Regulation of the port also summarized in some aspects related to the activities of Public Authority in port which cover action of stowaway, which is based on act of the Contracting Government to ensure the establishment of the infrastructure or oprational regulation including required security for the prevention purpose of person who stow away to the ship without permission for gaining access to port installations or ships through an integrated part of the port. ${ }^{41}$ Annex also stipulates that the public authorities must also manage facilities that help to expedite the process of arrival and departure of ships, either by establishing a specific installation that will ease the passenger, ${ }^{42}$ ship's crew, also cargo and baggage loading or unloading process.

\footnotetext{
${ }^{36}$ Ibid., 7.4 .

${ }^{37}$ Ibid., 7.6.

${ }^{38}$ Ibid., 7.2.

${ }^{39}$ Ibid., 7.5 .

${ }^{40}$ Ibid., 7.7.

${ }^{41}$ Annex of Convention on Facilitation of Maritime Traffic 1966 Section 4 - Stowaways, 4.3.1.1.

${ }^{42}$ In terms of passengers, it should be noted also the necessity to provide adequate facilities for passengers who are elderly or who have a disability as provided for in Section 3 - Arrival and departure
} of persons. 


\section{International Convention for Safe Containers 1972}

The use of containers is an important aspect in the delivery of goods by sea, the fact encourages the International Maritime Organization (IMO) and the Economic Commission for Europe prepare a draft of the Convention relating to the safety aspects in goods packaging using containers for the interest of the delivery of goods by sea. The draft convention was adopted in 1972 at a conference convened by IMO together with the United Nations (UN) with the title of the International Convention for Safe Containers 1972 (CSC 1972).

The purpose of the formulation of the CSC in 1972, among others, to manage the high level of safety aspects in the activities of transport and handling of containers by providing a commonly accepted test procedure and requirements related to the strength of the container. In addition, CSC 1972 is intended to facilitate the international transport modes to provide a container with international safety regulations that apply equally to all modes of transportation available.

Requirements stipulated in the 1972 CSC applies to the majority of containers used internationally, except those specifically designed for the carriage by air. In addition, the Convention also has two annexes which discusses testing, inspection, and container management as well as a structured security test which includes detailed test procedures.

\section{International Convention for the Safety of Life at Sea 1974 dan International Ship and Port Facilities Security Code (ISPS Code)}

History on safety at sea has been going since long, but the sinking of Titanic on April 14, 1912 ingnited international community's initiative to see a standard of safety at sea which then initiated the birth of a Intenasional Convention governing the issue. ${ }^{43}$ The British government then proposed the holding of a conference that is expected to discuss the formulation of the Convention, which was attended by representatives from 13 countries. ${ }^{44}$ The conference resulted in a Convention as the International Convention for the Safety of Life at Sea (known as SOLAS Convention) on January 20,1914 which introduced a new international regulation related to safety of navigation, provision of watertightand fireresistant bulkheads, life-saving devices, as well as prevention fires and fire fighting devices on passenger ships. ${ }^{45}$

Regulation of the port mainly summarized in Regulation XI-2/6 which includes requirements for port facilities, which provide other things for Contracting Governments to ensure the safety assessment of the facility is well run and port facility security plans are developed, implemented and assessed in accordance with ISPS Code.

Formulation of the ISPS Code is motivated by the terrorist attacks on 11 September 2001 in the United States, which then encourages the approval of the development of a new measure related to the security of the ship and port facilities for adoption by the Conference of Contracting Governments of to the

\footnotetext{
${ }^{43}$ International Maritime Organization, "History of Solas", <http://www.imo.org/KnowledgeCentre/ReferencesAndArchives/HistoryofSOLAS/Pages/default.aspx>, last accessed August 30, 2013.

${ }^{44}$ Ibid.

${ }^{45}$ SOLAS Convention 1914 took effect in 1915 caused by a devastating war in Europe at the time.
} 
International Convention for the Safety of Life at Sea in December 2002 in the 22nd session of the Assembly of the International Maritime Organization. ${ }^{46}$ After the adoption of the ISPS Code, the provisions of Chapter XI-2 of SOLAS Convention and Code are then applicable to ships and port facilities. Expansion of the SOLAS Convention to include port facility approved on the basis that SOLAS Convention offers the fastest way to ensure the necessary security measures apply and take effect quickly. ${ }^{47}$

ISPS Code itself is divided into two parts, where part A shall contain provisions related to the security of ships and port facilities and part B provides an overview of the best practices that can be performed by the Contracting Governments to comply with the mandatory provisions set out in section A. Indonesia which is the party of the SOLAS Convention ${ }^{48}$ has applied ISPS Code by Decree of the Minister of Transport of the Republic of Indonesia No. 33 of 2003 on the Application of Amendments to SOLAS 1974 on the Security of Ships and Port Facilities (International Ship and Port Facility Security Code) in Indonesian territory that formally took effect since 1 July 2004.

\section{B. National Legislations in Port Sector}

\section{Law No. 17 Year 2008 on Shipping}

Shipping Law of 2008 is the rule governing the port in general. This regulation governs the general aspects that must be passed and is owned by a port that has its own standard.

Ports are places which consists of land and/or water with certain limits as a government activity and business activity took place, used as place to docking ships, loading and unloading passengers, and/or goods, in the form of terminals and berths which are equipped with shipping safety and security facility and supporting activities as well as the intra and inter-mode movement of transportation. ${ }^{49}$ To build and repair port in accordance with what is required by the public, it is required a series of planning called Order of the National Ports (Tatanan Kepelabuhanan Nasional). Order of the National Ports is a national port system that describes the planning of port based economic area, geography, and the comparative advantage of the region, as well as natural conditions. ${ }^{50}$ Order of the National Ports materialized in the course of reliable and highly capable port management, ensures efficiency, and has global competitiveness to support national and regional development with archipelagic insight (Wawasan Nusantara). ${ }^{51}$ Order of the National Ports consists of ${ }^{52}$ :

a. Role, functions, types, and port hierarchy;

b. National Ports Master Plan; and

${ }^{46}$ International Ship and Port Facility Security Code, Preamble, par. 2.

${ }^{47}$ Ibid., par. 5.

${ }^{48}$ Indonesia's Ratification of SOLAS Convention is done by Presidential Decree No. 75 of 1980 on "Ratification of International Convention for the Safety of Life at Sea 1974 (Pengesahan International Convention for the Safety of Life at Sea 1974)".

${ }^{49}$ Indonesia (1), Law on Shipping, Law No. 17 of 2008, State Gazette No. 64 of 2008. TLN No. 4849, Art. 1 point 16 .

\footnotetext{
${ }^{50}$ Ibid. Art. 67 par. (2).

${ }^{51}$ Ibid. Art. 67 par. (1).

52 Ibid. Art. 67 par. (3).
} 
c. Port location.

The port has an important role in order to materialize the demands and needs of the community for their ports, namely as: ${ }^{53}$

a. node in the transportation network in accordance with the hierarchy;

b. gates of economic activity;

c. place of transportation mode switching activities;

d. supporting industrial activities and/or trade;

e. place of distribution, production, and consolidation of cargo or goods; and

f. materialize Archipelagic insight and sovereignty of the country.

Port also serves as the place of government activity and business activity. ${ }^{54}$ These activities must be conducted in an integrated and coordinated manner. ${ }^{55}$ The said goverment activities must include the following functions ${ }^{56}$ :

a. regulation and guidance, control, and monitoring of port activities; and

b. safety and security of shipping.

c. customs;

d. immigration;

e. quarantine; and / or

f. other non-permanent government activities. ${ }^{57}$

For the activities referred to in points (a) the regulation and guidance, control, and monitoring of port activities, carried out by the organizers of the port ${ }^{58}$ For the activities referred to in points (b) the safety and security of shipping, carried out by the harbor master. ${ }^{59}$ While the function of customs, immigration, and kekarantinaan carried out in accordance with the legislation. ${ }^{60}$

Business activities at the port consist of the provision and/or port service and port-related services. ${ }^{61}$ Port service activities, including the provision and/or services ships, passengers and goods ${ }^{62}$, including ${ }^{63}$ :

a. provision and/or dock services to tie up;

b. provision and/or refueling service and water services;

c. provision and/or service facilities to load and unload the passenger and/or vehicle;

d. provision and/or dock service to held goods and containers loading or unloading activity.

e. provision and/or warehouse services and stockpiling, loading and unloading equipment, as well as port equipment;

\footnotetext{
${ }^{53}$ Ibid. Art. 68.

${ }^{54}$ Ibid. Art. 69.

55 Ibid. Art. 79.

${ }^{56} \mathrm{Ibid}$. Art. 80 par. (1).

${ }^{57}$ Ibid. Art. 80 par. (2).

${ }^{58}$ Ibid. Art. 80 par. (3).

${ }^{59}$ Ibid. Art. 80 par. (4).

${ }^{60}$ Ibid. Art. 80 par. (5).

${ }^{61}$ Ibid. Art. 90 par. (1).

${ }^{62}$ Ibid. Art. 90 par. (2).

${ }^{63}$ Ibid. Art. 90 par. (3).
} 
f. provision and/or container terminal services, liquid bulk, dry bulk, and RoRo;

g. provision and/or stevedoring services;

h. provision and/or distribution service center and consolidation of goods; and/or

i. provision and/or tug ship services.

While, service activity related to the port consists of activity that support the operations and provide a added value to the port. ${ }^{64}$ Activity in the provision and/ or port service activity in commercial port managed by port enterprises inline with the type of owned business permit. ${ }^{65}$ Activity of providing and/or port service on a non-commercial port is implemented by the Port Operator Unit (Unit Penyelenggara Pelabuhan) ${ }^{66}$ Activities associated with the port services can be performed by Indonesian national and/or entities. ${ }^{67}$ Activity of providing and/or port service that is performed by business entities based on concession or any other form by Port Authority, concluded in an agreement. ${ }^{68}$ Port Enterprises acts as the operator which operates the terminals and other port facilities. ${ }^{69}$

Port organizers consist of Port Authority and Port Operator Unit. ${ }^{70}$ Port Authority establised in commercial ports. ${ }^{71}$ While the Port Operator Unit established in non-commercial port. ${ }^{72}$ Port Operator Unit may in form as Governmental Port Operator Unit and Local Government Port Operator Unit. ${ }^{73}$

To carry out the regulation and supervision, control, and monitoring function of port activity Port Authority has duties and responsibilities as follows: ${ }^{74}$

a. provide land and waters in port;

b. provide and maintain the retaining wave pool, harbor, shipping lanes, and roads;

c. provide and shipping and navigation supporting facility (Sarana Bantu Navigasi Pelayaran);

d. ensure security and order in the port;

e. ensure and maintain environmental sustainability in the port;

f. prepare Port Master Plan (Rencana Induk Pelabuhan), also Working Environment Area (Daerah Lingkungan Kerja) and, Port Interest Environment Area (Daerah Lingkungan Kepentingan Pelabuhan);

g. propose tariff to be set by the Minister, on the use of water and/or land, and port facilities provided by the Government as well as port services organized by the Port Authority in accordance with the provisions of the legislation;

\footnotetext{
${ }^{64}$ Ibid. Art. 90 par. (4).

${ }^{65}$ Ibid. Art. 91 par. (1).

${ }^{66}$ Ibid. Art. 91 par. (3).

${ }^{67}$ Ibid. Art. 91 par. (5).

${ }^{68}$ Ibid. Art. 92.

${ }^{69}$ Ibid. Art. 93.

${ }^{70}$ Ibid. Art. 81 par. (1).

${ }^{71}$ Ibid. Art. 81 par. (2).

${ }^{72}$ Ibid. Art. 81 par. (3).

${ }^{73}$ Ibid. Art. 81 par. (4).

${ }^{74}$ Ibid. Art. 83 par. (1).
} 
h. ensure the smooth flow of goods; and

i. conducting supply and/or port service required by service users which have not been provided by the Port Enterprises. ${ }^{75}$

To carry out the duties and responsibilities, the Port Authority has the authority to: ${ }^{76}$

a. regulate and supervise land and water utilization;

b. supervise the use of the Working Environment Area and, Port Interest Environment Area.

c. regulate inbound and outbound ship traffic through the port pilotage; and

d. establish standards of operational performance of port service.

Port Operator Unit has duties and responsibilities:

a. provide and maintain the wave retainer, port pool, and shipping flow;

b. provide and maintain shipping and navigation supporting facility (Sarana Bantu Navigasi Pelayaran);

c. ensure security and order in the port;

d. maintaining environmental sustainability in the port;

e. prepare Port Master Plan (Rencana Induk Pelabuhan), also Working Environment Area (Daerah Lingkungan Kerja) and, Port Interest Environment Area (Daerah Lingkungan Kepentingan Pelabuhan);

f. ensure the smooth flow of goods; and

g. provide port facilities.

National Ports Master Plan (Rencana Induk Pelabuhan Nasional) shall contain the national ports policy and plan the location and port hierarchy. ${ }^{77}$ Minister of Transportation establishes the National Port Master Plan for a period of 20 (twenty) years. ${ }^{78}$ National Ports Master Plan can be reviewed 1 (one) time in 5 (five) years. ${ }^{79}$ In the event of strategic changes in the environmental conditions by disaster stipulated by the provisions of the laws and regulations, National Port Master Plan can be reviewed more than 1 (one) time in 5 (five) years. ${ }^{80}$

Port Master Plan shall include a allocation plan of land and water area of each facility based on the criteria of principal and supporting facilities. ${ }^{81}$ Activities to support the trading ports open to international trade is done by the main port. ${ }^{82}$ Determination of the port carried out by the following considerations: ${ }^{83}$

a. growth and development of national economy;

b. international trade interests;

c. interest of national Navy development;

d. geographical position which located in international sea lanes;

\footnotetext{
${ }^{75}$ Ibid. Art. 83 par. (2).

${ }^{76}$ Ibid. Art. 84.

${ }_{77}$ Ibid. Art. 71 par. (3).

${ }^{78}$ Ibid. Art. 71 par. (4).

${ }^{79}$ Ibid. Art. 71 par. (5).

${ }^{80} \mathrm{Ibid}$. Art. 71 par. (6).

81 Ibid. Art. 74.

${ }^{82}$ Ibid. Art. 111 par. (1).

${ }^{83}$ Ibid. Art. 111 par. (2).
} 
e. Order of the national ports;

f. port facilities;

g. security and national sovereignty; and

h. other national interests.

Certain special terminal can be used to conduct foreign trade activity. ${ }^{84}$ Certain special terminal shall meet the requirement: ${ }^{85}$

a. administration aspect;

b. economical aspect;

c. shipping safety and security aspect;

d. port facility technical aspect;

e. office facility and supporting facility for institution which hold shipping safety and security function, customs, immigration, and quarantine; and

f. certain kind of commodity.

The role of the port, as described previously, is done to provide benefits for local governments. ${ }^{86}$ Attempts to provide such benefits, the local government have a role, duties, and authority as follows: ${ }^{87}$

a. encourage the development of trade area, industrial area, and other economic activity centers;

b. supervise assured environmental sustainability in the port;

c. help ensure the safety and security of the port;

d. provide and maintain the infrastructure that connects the port to the area of trade, industrial, and other economic activity centers;

e. fostering communities around the port and facilitate communities in the region to be able to participate in a positive way the implementation of port activities;

f. providing cargo information center at the regional level;

g. provide building permits in the mainland; and

h. provide recommendations for the designation of specific ports and terminals.

In terms of local government can not carry out or abusing the role, duties, and authority, the Central Government can take over the role, duties, and powers in accordance with the provisions of laws and regulations. ${ }^{88}$

\section{Government Regulation No. 61 of 2009 on Ports}

Government Regulation No. 61 of 2009 on Ports is a further regulation of the Law 17 of 2008 on Shipping. The Government Regulation governs how the port to be effective and efficient in serving the large volume of the demand for seaports services.

Ports are places which consists of land and/or water with certain limits as a government activity and business activity took place, used as place to docking

\footnotetext{
${ }^{84}$ Ibid. Art. 111 par. (3).

${ }^{85}$ Ibid. Art. 111 par. (4).

${ }^{86}$ Ibid. Art. 114.

${ }^{87}$ Ibid. Art. 115 par. (1).

${ }^{88}$ Ibid. Art. 115 par. (2).
} 
ships, loading and unloading passengers, and/or goods, in the form of terminals and berths which are equipped with shipping safety and security facility and supporting activities as well as the intra and inter-mode movement of transportation. ${ }^{89}$ To build and repair port in accordance with what is required by the public, it is required a series of planning called Order of the National Ports (Tatanan Kepelabuhanan Nasional). ${ }^{90}$ Order of the National Ports is a national port system that describes the planning of port based economic area, geography, and the comparative advantage of the region, as well as natural conditions. ${ }^{91}$ Order of the National Ports materialized in the course of reliable and highly capable port management, ensures efficiency, and has global competitiveness to support national and regional development with archipelagic insight (Wawasan Nusantara). ${ }^{92}$ Order of the National Ports consists of ${ }^{93}$ :

a. Role, functions, types, and port hierarchy;

b. National Ports Master Plan; and

c. Port location.

The port has an important role in order to materialize the demands and needs of the community for their ports, namely as ${ }^{94}$ :

a. node in the transportation network in accordance with the hierarchy;

b. gates of economic activity;

c. place of transportation mode switching activities;

d. supporting industrial activities and/or trade;

e. place of distribution, production, and consolidation of cargo or goods; and

f. materialize Archipelagic insight and sovereignty of the country.

Port also serves as the place of government activity and business activity. ${ }^{95}$ The said goverment activities must include the following functions 96 :

a. regulation and guidance, control, and monitoring of port activities; and

b. safety and security of shipping.

c. customs;

d. immigration;

e. quarantine; and / or

f. other non-permanent government activities.

For the activities referred to in points (a) the regulation and guidance, control, and monitoring of port activities, carried out by the organizers of the port, which consists of Port Authority for the commercial ports, and Port Operator Unit for non-commercial ports. ${ }^{97}$

Port Authority established in commercial ports has duties and responsibilities as

${ }^{89}$ Indonesia (2), Peraturan Pemerintah Kepelabuhanan (Government Regulation on Ports), PP No. 61 Tahun 2009, State Gazette No. 151 of 2009. TLN No. 5070, Art. 1 par. (1).

${ }^{90}$ Ibid. Art. 1 par. (3).

${ }^{91}$ Ibid. ps. 3 par. (2).

${ }^{92}$ Ibid. Art 3 par. (1).

${ }^{93}$ Ibid. Art 3 par. (3).

${ }^{94}$ Ibid. Art 4.

${ }^{95}$ Ibid. Art 5.

${ }^{96}$ Ibid. Art 37.

${ }^{97}$ Ibid. Art 38. 
follows ${ }^{98}$ :

a. provide land and waters in port;

b. provide and maintain the retaining wave pool, harbor, shipping lanes, and roads;

c. provide and shipping and navigation supporting facility (Sarana Bantu Navigasi Pelayaran);

d. ensure security and order in the port;

e. ensure and maintain environmental sustainability in the port;

f. prepare Port Master Plan (Rencana Induk Pelabuhan), also Working Environment Area (Daerah Lingkungan Kerja) and, Port Interest Environment Area (Daerah Lingkungan Kepentingan Pelabuhan);

g. propose tariff to be set by the Minister, on the use of water and/or land, and port facilities provided by the Government as well as port services organized by the Port Authority in accordance with the provisions of the legislation;

h. ensure the smooth flow of goods; and

i. conducting supply and/or port service required by service users which have not been provided by the Port Enterprises. ${ }^{99}$

Then, the Port Operator Unit established on commercial port, established by and also simultaneously responsible to the Minister for Governmental Ports Operator Units and Governor or Regent/Mayor for the Port Operator Units of Local Government ${ }^{100}$ In carrying out the functions of regulation and supervision, control, and monitoring of port activities, the Port Operator Unit has duties and responsibilities ${ }^{101}$ :

a. provide and maintain the wave retainer, port pool, and shipping flow; ${ }^{102}$

b. provide and maintain shipping and navigation supporting facility (Sarana Bantu Navigasi Pelayaran);

c. ensure security and order in the port;

d. maintaining environmental sustainability in the port;

e. prepare Port Master Plan (Rencana Induk Pelabuhan), also Working Environment Area (Daerah Lingkungan Kerja) and, Port Interest Environment Area (Daerah Lingkungan Kepentingan Pelabuhan);

f. ensure the smooth flow of goods; and

g. provide port facilities.

For the shipping safety and security functions carried out by harbormaster, who can execute it includes the implementation, monitoring, and law enforcement in the field of water transport, ports, maritime environmental protection in the port, helping the conduct of search and rescue in the port in accordance with the provisions of the legislation. ${ }^{103}$ For functions related customs, immigration, and quarantine and/or other non-permanent government activity, conducted in

${ }^{98}$ Ibid. Art 42.

${ }^{99}$ Ibid. Art. 83 par. (2).

${ }^{100}$ Indonesia (2), op.cit., Art 44 par. (1) dan (2).

101 Ibid. Art. 44 par. (3).

102 Pada Art. 44 par. (4) Certain natural condition, maintenance of wave barrier, port poool, and sea lane can be carried out by terminal operator for its own account as outlined in the concession agreement.

${ }^{103}$ Ibid. Art 39. 
accordance with the legislation. ${ }^{104}$

Embodiments of the National Order of port are the National Port Masterplan (Rencana Induk Pelabuhan Nasional). ${ }^{105}$ The goal is to be used as a guide in determining the location, construction, operation, port development, and preparation of the Port Master Plan. National Ports Master Plan is a national port development for the long term ${ }^{106}$ and includes national ports policy and plan the location and port hierarchy. ${ }^{107}$ National ports policy includes the development orientation of the port, both for existing and new port development orientation, so that the port managements can work in synergy and give mutual support between one and the other. ${ }^{108}$

Usage rates of waters and/or lands and port services which conducted by Port Authority appointed by Port Authority after consultation with Minister of Transportation.109 Port service rate which managed by Port Enterprises based on type, structure, and rate groups set by Minister, is an income for Port Enterprises.110 Port service rate for ports which are managed as a noncommercial port by Government set by Government Regulation, and it is a nontax revenue.111 Port service rate for ports which are managed by Provincial Government and Regency/City Government set by Local Regulation (Peraturan Daerah), and it is a local government revenue ${ }^{112}$

To support the international trade, main ports and certain specific terminal can be set as an open port for foreign trade ${ }^{.113}$ Decision as referred to in paragraph (1) take full account of: ${ }^{114}$

a. growth and development of national economy;

b. international trade interests;

c. interests of national Navy development;

d. geographical position which located on international sea lane;

e. Order of the National Port which realized in form of National Port Master Plan;

f. port facility;

g. national security and sovereignty; and

h. other national interests.

The port specified by the Minister of Transport at the request of the organizers of the major port after fulfilling the requirements. ${ }^{115}$ It shall meet the requirements: ${ }^{116}$

a. economical aspect;

\footnotetext{
104 Ibid. Art 41.

105 Ibid. Art 7 par. (1).

${ }^{106}$ Ibid. Art 7 par. (2).

${ }^{107}$ Ibid. Art 8 par. (1).

${ }^{108}$ Ibid. Art 9.

${ }^{109}$ Ibid. Art. 147 par. (1).

${ }^{110}$ Ibid. Art. 147 par. (2).

${ }^{111}$ Ibid. Art. 147 par. (3).

112 Ibid. Art. 147 par. (4).

113 Ibid. Art. 149 par. (1).

${ }^{114}$ Ibid. Art. 149 par. (2).

115 Ibid. Art. 150 par. (1).

${ }^{116}$ Ibid. Art. 150 par. (2).
} 
b. shipping safety and security aspect;

c. port facility technical aspect;

d. office facility and supporting facility for institution which hold shipping safety and security function, customs, immigration, and quarantine; and

e. certain kind of commodity.

Certain special terminal specified by Minister of Transport at the request of the organizers of the special terminal after fulfilling the requirements. ${ }^{117}$ The requirement mentioned in paragraph (1) shall meet: ${ }^{118}$

a. administration aspect;

b. economical aspect;

c. shipping safety and security aspect;

d. port facility technical aspect;

e. office facility and supporting facility for institution which hold shipping safety and security function, customs, immigration, and quarantine; and

f. certain kind of commodity.

\section{Presidential Decree No. 5 of 2010 on Medium-term National Development Plan 2010-2014.}

Presidential Decree No. 5 of 2010 on Medium-term National Development Plan 2010-2014 is guidance for goverment to conduct and improve the development in Indonesia for term 2010 - 2014. In Medium-term National Development Plan (Rencana Pembangunan Jangka Menengah; abbreviated as RPJM) there are plans for development of ports in Indonesia. In the goals of economic development and welfare in field of infrastructure, Government continues the development and supply of infrastructure shown by increasing quality and quantity of various supporting infrastructure for development, specially the seaports. ${ }^{119}$ In national priority program, infrastructure development positioned as the sixth priority. Infrastructure development is set on the fields of transportation infrastructure network development and the provision of integrated intermodal and interisland transportation according to the National Transportation System and Multimodal Transportation Blueprint and reduction of transport accidents so that in 2014 it become less than $50 \%$ of the current condition. ${ }^{120}$

On the infrastructure program, the government has the Management and Operation of the program activities in the field of Ports and Dredging. The intended target is the availability of 15 navigational ships, availability of safe navigation channel for ships through dredging $61.7150 .00 \mathrm{~m} 3$ of sediment, and establishment/increased capacity of 275 locations of infrastructure and major port facilities, collector, and feeder (non-strategic). ${ }^{121}$

Specifically, there is a priority of developing port infrastructure network as the part of maritime transportation network systems. It is performed dynamically and regarded order of the national port according to its handling priorities,

\footnotetext{
${ }^{117}$ Ibid. Art. 151 par. (1).

118 Ibid. Art. 151 par. (2).

${ }^{119}$ Annex of Presidential Decree No. 5 of 2010 on RPJMN 2010-2014, p. 45.

${ }^{120}$ Ibid., p. 57.

121 Ibid, p. 71.
} 
including:

1. Sumatera

a. Batam as the hub international port since it has geographical location relatively close to port of Singapore, so the built strategiy is the Port of Batam as a complementary set of the Port of Singapore and forward gradually developed as an international hub port.

Other ports that can be projected as an international hub port is Belawan (current status as international ports) primarily to serve the liquid / bulk cargo. Other ports on the island of Sumatra will act as a feeder for the Port of Batam.

b. International port in Teluk Bayur-Padang and Dumai.

c. National ports in Malahayati, Meulaboh, Lhokseumawe, Tanjung Pinang, Sibolga, Pekanbaru/ Tanjung Buton, Pulau Baai, Tanjung Balai Karimun, Tanjung Balai Asahan, Tembilahan, Ranai, Kuala Tanjung, Moro Sulit, Muara Sabak, Tanjung Batu, Tanjung Kedabu, Rengat, Pulau Kijang, Kuala Enok, Perawang, Pulau Sambu, Singkep - Dabo, Sungai Pakning, Buatan, dan Panjang.

d. Regional ports in Singkil, Kuala Langsa, Pangkalan Brandan, Bagansiapiapi, Pangkalan Dodek, Gunung Sitoli, Teluk Dalam, Sinabang, Bintuhan, Kuala Gaung, Kuala Tungkal, Nipah Panjang, Panipahan, Panjalal, Serasan, Sungai Liat, Tanjung Api-Api/Palembang, Kota Agung, Sungai Guntung, dan Bakauheni.

e. Local ports in Tanjung Kedabu and Pulau Kijang

2. Java - Bali

a. International hub port candidates in Tanjung Priok/Bojanegara dan Tanjung Perak - Surabaya.

b. The development shall integrated with processing/industrial zone activities nearby;

c. International ports in Tanjung Emas - Semarang, Merak - Banten, Arjuna - Cirebon, Tanjung Intan - Cilacap, and Benoa - Bali;

d. National ports in Cigading, Karangantu, Subang, Kalibaru, Muara Baru, Sunda Kelapa, Marunda, Pulau Kelapa, Kepulauan Seribu, Juwana, Kamal, Tanjung Wangi, Bawean, Gresik, Pasuruan, Probolinggo, Paiton, Kalbut, Kangean, Sapudi, Sapeken, Celukan Bawang, Gilimanuk, and Padang Bai;

e. Regional ports in Muara Gembong, Pangandaran, Kajawanan, Muara Gebang, Indramayu, Palabuhan Ratu, Muara Cikeuwis, Labuan, Anyer Lor, Muara Angke, Batang, Brebes, Jepara, Karimun Jawa, Rembang, Tegal, Banyuwangi, Panarukan, Brondong, Telaga Biru, Kalianget, Tuban, Buleleng, Nusa Penida dan Sangsit.

3. Borneo

a. Port of Pontiakan can be developed through capacity building of its service, with the position as international port, and expected later as feeder for Port of Batam. Development of Port of Pontianak is an anticipation against influence of BIMP-EAGA.

b. Whereas in the Eastern side of Borneo, Port of Tarakan (currently has the status as national port) chosen to be developed in accordance with 
its service capacity, and other candidates are Port of Samarinda and Balikpapan as international port.

c. National ports in Kandawangan Kotabaru, Ketapang, Paloh/Sakura, Sambas, Sintete, Telok Air, Kumai, Pangkalan Bun, Pulau Pisau, Sampit, Sukamara, Sei Danau/Satui, Sebuku/Batulicin, Simpang Empat/ Batulicin, Stagen, Kampung Baru, Tanah Grogot, Nunukan, Pulau Bunyu, Sangatta, Tanjung Laut, Tanjung Redeb, Tanjung Santan, and Tarakan.

d. Regional ports in Pagatan, dan Sangkulirang.

4. Sulawesi

a. International hub port candidate in Bitung with the consideration based on closeness of its location with international market water, Asia Pacific and anticipation against BIMP-EAGA.

b. International port in Makassar.

c. National ports in Gorontalo, Anggrek, Kwandang, Tahuna, Manado, Tagulandang, Labuhan Uki, Kolonodale, Baubau, Kendari, Donggala, Tolitoli, Banggai, Luwuk, Poso, Kolaka, Pagimana, Ampana, Malili, Barru, Parepare, Bajoe, Bulukumba, Palopo, Mamuju, Selayar, Sinjai, Lirung, Belangbelang, Jeneponto, Siwa and Raha.

d. Regional ports in Tilamutu, Mejene, Lasalimu, Keledupa, Parigi and Lokodidi.

e. Local ports in Tabulo, Siau, Likupang, Beo and Amurang.

5. Nusa Tenggara Islands

a. High priority for international port in Kupang, medium priority for national ports in Labuhan Lombok, Maumere, Waingapu, Lembar, and Bima.

b. Medium priority for regional ports in Tanjung Luar (current status as local ports), P. Kempo (current status as local ports), Cempi, Mbay, and Reo.

6. Moluccas

a. National ports in Ternate, Ambon, Dobo, Tual, Tulehu, Tobelo, Saumlaki and Labuha with high priority;

b. Regional ports in Babang, Mafa, Sanana, Dofa (current status as local port), Bobong (current status as local port), and Buli with medium priority.

7. Papua

a. National ports Jayapura, Manokwari, Sorong and Biak;

b. National port in Sorong projected to be international port.

\section{Ministrial Regulation concerning Ports}

a. Ministry of Transport Regulation No. PM 34 of 2012 on Organization, and Working Procedure for Main Harbormaster Office.

Ministry of Transport Regulation No. PM 34 of 2012 on Organization, and Working Procedure for Main Harbormaster Office. Main Harbormaster Office (Kantor Kesyahbandaran Utama) is a Technical Implementation Unit 
in Ministry of Transportation which is subordinate and accountable to the Director General of Sea Transportation. ${ }^{122}$ Main Harbormaster Office led by a Chief. ${ }^{123}$ Main Harbormaster Office has the tasks of monitoring and law enforcement in the field of shipping safety and security, as well as the coordination of government activities in the harbor. ${ }^{124}$ In performing these duties, Main Harbormaster Office performs following functions: ${ }^{125}$

1) performing supervision of compliance of seaworthiness of the ship, safety, security and order in the port as well as the issuance of the Letter of Sailing Approval;

2) performing supervision over ship traffic order in harbor water and shipping lane;

3) performing supervision over the load transfer in the harbor waters, underwater activities and salvage, pilotage and tug ship;

4) performing supervision on shipping safety and security in activitiy related to loading and unloading dangerous goods, special goods, hazardous and toxic waste, refueling, order of passengers embarkation and disembarkation, construction of port's facility, dredging and reclamation;

5) execution of a search and rescue assistance, control and coordination of pollution prevention and fire fighting in the port as well as monitoring the implementation of the protection of the maritime environment;

6) investigation of the ship accidents;

7) law enforcement in the field of shipping safety and security with accordance of laws and regulations;

8) coordination of government activities in the port associated with the implementation of monitoring and law enforcement in the field of safety and security of shipping; and management of business administration, personnel, finance, law and public relations.

b. Ministry of Transport Regulation No. PM 35 of 2012 on Organization and Working Procedures of Main Port Authority Office

Ministry of Transport Regulation No. PM 35 of 2012 governs organization and working procedures of Main Port Authority Office. Main Port Authority Office is a Technical Implementation Unit in Ministry of Transportation which is subordinate and accountable to the Director General of Sea Transportation. ${ }^{126}$ Main Port Authority Office is led by a Chief. ${ }^{127}$ Main Port Authority Office has the tasks of regulation, control and supervision of port activities in the commercial ports. ${ }^{128}$

${ }^{122}$ Indonesia (3), Peraturan Menteri Perhubungan tentang Organisasi dan Tata Kerja Kantor Kesyahbandaran Utama (Ministry of Transport Regulation on Organization, and Working Procedure for Main Harbormaster Office), PM No. 34 on 2012, Berita Negara No.627 Tahun 2012, Art. 1 par. (1).

${ }^{123}$ Ibid. Art. 1 par. (2)

124 Ibid. Art. 2.

125 Ibid. Art. 3.

${ }^{126}$ Indonesia (4), Peraturan Menteri Perhubungan tentang Organisasi dan Tata Kerja Kantor Otoritas Pelabuhan Utama (Ministry of Transport Regulation on Organization and Working Procedures of Main Port Authority Office), PM No. 35 Tahun 2012, Berita Negara No.628 Tahun 2012, Art. 1 par. (1).

${ }^{127}$ Ibid. Art. 1 par. (2).

${ }^{128}$ Ibid. Art. 2. 
In performing these duties, the Office of the Main Port Authority performs functions: $:^{129}$

1) implementation of the provision, regulation, and supervision of utilization of land and waters;

2) provide and maintain the retaining wave pool, harbor, shipping lanes, and roads;

3) provide and maintain the shipping and navigation supporting facility (Sarana Bantu Navigasi Pelayaran);

4) ensure and maintain environmental sustainability in the port;

5) prepare Port Master Plan (Rencana Induk Pelabuhan), also Working Environment Area (Daerah Lingkungan Kerja) and, Port Interest Environment Area (Daerah Lingkungan Kepentingan Pelabuhan)

6) propose tariff to be set by the Minister, on the use of water and/or land, and port facilities provided by the Government as well as port services organized by the Port Authority in accordance with the provisions of the legislation;

7) Implementation of inbound and outbound ship traffic management trough ship pilotage;

8) Safety and security assurance, and ensure the smooth flow of goods;

9) conducting supply and/or port service required by service users which have not been provided by the Port Enterprises.

10) implementation of the granting of concessions or other form to the Port Business Entity to perform business activities in the port;

11) preparation of evaluation materials for evaluation of operational performance stanrdards of port service; and

12) management of administration, personnel, financial, law, and public relation.

c. Ministry of Transport Regulation No. PM 36 of 2012 on Organization and Working Procedures of Harbormaster Office and Port Authority

Ministry of Transport Regulation No. PM 36 of 2012 on Organization and Working Procedures of Harbormaster Office and Port Authority. The purpose of this regulation is to increase the effectiveness and efficiency of implementation of tasks and functions in the field of safety and security of shipping, as well as regulation, control and supervision of port activities

Harbormaster Office and Port Authority is a Technical Implementation Unit in the Ministry of Transportation, which is subordinate and accountable to the Director General of Sea Transportation. ${ }^{130}$ Harbormaster Office and Port Authority are led by a Chief. ${ }^{131}$ Harbormaster Office and Port Authority has the task of carrying out supervision and law enforcement in the field of safety and security of shipping, coordination of government activities in the harbor as well as the regulation, control and monitoring of port activities in

${ }^{129}$ Ibid. Art. 3.

${ }^{130}$ Indonesia (5), Peraturan Menteri Perhubungan tentang Organisasi dan Tata Kerja Kantor Kesyahbandaran dan Otoritas Pelabuhan (Ministry of Transport Regulation on Organization and Working Procedures of Harbormaster Office and Port Authority), PM No. 36 Tahun 2012, Berita Negara No.629 Tahun 2012, Art. 1 par. (1).

${ }^{131}$ Ibid. Art. 1 par. (2). 
the commercial port. ${ }^{132}$

In performing its duties Harbormaster Office and Port Authority performs functions: $:^{133}$

1) Performing supervision and compliance of seaworthiness of the ship, safety certification for ship, contamination prevention from ships and determination of legal status of the ship;

2) Performing inspection of safety management of ship;

3) Performing supervision of safety and security of shipping associated with the loading and unloading of dangerous goods, special goods, hazardous materials and toxic waste, refueling, embarkation and disembarkation of passengers order, port Facilities construction, dredging and reclamation, and seaworthiness, ship traffic order in the harbor waters and shipping lanes, pilotage and tugging of ship, as well as the issuance of the Letter of Sailing Approval;

4) Performing investigation in case of ship accident, prevention and;

5) pelaksanaan pemeriksaan kecelakaan kapal, prevention and fire fighting in the harbor waters, the handling of the disaster at sea, maritime environmental protection implementation and enforcement in the field of safety and security of shipping;

6) Performing coordination of government activities in field related with supervision and enforcement in the field of safety and security of shipping;

7) Performing preparation of Port Master Plan, Working Environment Area, Port Interest Environment Area, and monitoring its use, proposal for rates to be set by Minister;

8) Performing provision, regulation, and supervision utilization of land and waters, wave barrier maintenance, ports poool, shipping lanes and roans, and shipping and navigation supporting facility (Sarana Bantu Navigasi Pelayaran)

9) Performing assurance and maintenance of environmental sustainability at the port, security and order, the smooth flow of goods at the port;

10) Performing ship traffic control inbound and outbound the port through ship pilotage, provision and/or port service as well as concession granting or other forms to the Port Enterprises;

11) Performing materials for port service operational standards performance evaluation; and implementation of financial affairs, personnel and general affairs, law, and public relation, and reporting.

d. Ministry of Transport Regulation No. PM 6 of 2013 on Rates of Port Services Ministry of Transport Regulation No. PM 6 of 2013 governs Rates of port services that apply to the ports. Rate type of port service is a charge on any services provided by Port Authority, the Port Operator Unit and Port Enterprises to port services users. ${ }^{134}$ Rate type of port service consists of: ${ }^{135}$

${ }^{132}$ Ibid. Art. 2.

133 Ibid. Art. 3.

${ }^{134}$ Indonesia (6), Peraturan Menteri Perhubungan tentang Jenis, Struktur, dan Golongan Tarif Jasa Kepelabuhanan, PM No. 6 Tahun 2013, Berita Negara No.281 Tahun 2013, Art. 2 par. (1).

${ }^{135}$ Ibid. Art. 2 par. (2). 
1) ship service rate;

2) goods service rate;

3) passengers service rate; and

4) port related service rate

Ship services rate consists of: ${ }^{136}$

1) docking service rate;

2) pilotage service rate;

3) tugging service rate;

4) mooring service rate;

5) sea lane usage service rate;

6) mooring services rate.

Goods services rate consists of: ${ }^{137}$

1) common goods services rate in multi purpose terminal;

2) container services rate in container terminal;

3) liquid bulk cargo services rate in liquid bulk terminal;

4) dry bulk services rate in dry bulk terminal;

5) vehicle services rate in car terminal;

6) stevedoring services rate in floating terminal;

7) container services rate in dry port;

8) service rates of loading and unloading of vehicles and goods in Roll OnRoll Off (Ro-Ro) in Ro-Ro terminal

Passenger services rate consist of passengers and luggage of passengers. ${ }^{138}$

Port related services rate consist of: ${ }^{139}$

1) service rates for waste containment facility;

2) service rates for container depot;

3) service rates for warehousing;

4) service rates for cleaning and maintenance of office building;

5) service rates for fresh water installation;

6) service rates for power installation;

7) service rates for freshwater replenishment and refueling;

8) service rates for provision of office for port service user;

9) service rates for provision of cold storage facility;

10) service rates for ship maintenance and repairment;

11) service rates for packaging and labeling service;

12) service rates for fumigation and cleaning or container repairment;

13) service rates for public transportation from and to port;

14) service rates for vehicle parking service;

15) service rates for certain industrial activities;

16) service rates for trade activities;

17) service rates for provision of playground and recreation facility;

18) service rates for advertising service;

${ }^{136}$ Ibid. Art. 3 par. (1).

${ }^{137}$ Ibid. Art. 3 par. (2).

${ }^{138}$ Ibid. Art. 3 par. (3)

139 Ibid. Art. 4. 
19) service rates for hotel services, restaurant, tourism, postal and telecommunication services;

20) service rates for appliance services;

21) service rates for port entrance;

22) service rates for pond waste collection;

23) service rates for vehicle and goods using Ro-Ro;

24) inter-terminal transfer fees;

25) hi-co scan fees;

26) hi-co scan with behandle fees;

27) stacking costs (early stack) fees;

28) cancellation fees;

29) after closing time fees;

30) IT system for e-payment administration fees;

31) Stacking relocation fees;

32) ship mooring over stack fees; and

33) trucking fees.

\section{Conclusion}

After seeing at the various problems that exists in Indonesian ports, it is clear that the obstacles faced are not sufficient to be overcome with complete set of laws and regulations, but must be addressed as a whole. But at least when viewed from the laws and regulations, international law and national laws that apply there have been quite compability between international law regulation and Indonesian national law. But of course there are many provisions of international law related to the port that has not been followed by Indonesia, either because it has not ratified or because Indonesia is not ready to implement it. It is necessary for serious measures by port administrator and other concerned parties, in order for ports in Indonesia could be ready to face the globalization of international trade.

\section{Bibliography}

Alexandros M. Goulielmos and Agisilaos A. Anastasakos (2005). 'Worldwide Security Measures for Shipping, Seafarers and Ports: An Impact Assessment of ISPS code" 14(4) Disaster Prevention and Management: 462.

Carsten Fink et. al. (2002) "Trade in International Maritime Services: How Much Does Policy Matter?" 16(1) World Bank Economic Review: 81.

Greiger, T. (2011). Indonesia's Competitiveness: Sustaining the Growth Momentum. Geneve: World Economic Forum.

Hadiwinata, Bob Sugeng. (2002). Politik Bisnis Internasional. Yogyakarta: Kanisius.

Ismanthono, Henricus W. (2012). Kamus Istilah Ekonomi dan Bisnis. Jakarta: Kompas.

Jochen Erler. "The New Convention on Facilitation of International Maritime Traffic". McGill Law Journal, vol. 13, no. 2: 324.

Kindleberger, Charles P. (1973). The World in Depression, 1929-1939. Berkeley: University of California Press.

Nuryanto. (2011) “Implementasi Undang-undang Pelayaran: dapatkah Menghilangkan Monopoli Pelabuhan?: Jurnal Sains dan teknologi Maritim, Volume IX No. 2 Maret 2011. 
Ricardo J. Sanchez et. al., (2003) "Port Efficiency and International Trade: Port Efficiency As a Determinant of Maritime Transport Costs", 5 Maritime Economics \& Logistics: 199.

Saut Gurning. "Paradigma dan Orientasi Kebijakan Maritim Indonesia". Institut Teknologi Sepuluh November Surabaya,10 May 2011.

Spero, Edelman. (1981). The Politics of International Relations, $2^{\text {nd }}$ Ed., New York: St. Martin Press.

USAID \& SENADA. (2008) Reformasi Sektor Pelabuhan Indonesia dan UU Pelayaran Tahun 2008. Jakarta: SENADA.

Winarno, Budi. (2009). Pertarungan Negara vs. Pasar. Yogyakarta: Media Pressindo.

\section{Laws and Regulations}

Indonesia (1), Undang-Undang Pelayaran, UU No. 17 Tahun 2008, LN No. 64 Tahun 2008. TLN No. 4849.

Indonesia (2), Peraturan Pemerintah Kepelabuhanan, PP No. 61 Tahun 2009, LN No. 151 Tahun 2009. TLN No. 5070.

Indonesia (3), Peraturan Menteri Perhubungan tentang Organisasi dan Tata Kerja Kantor Kesyahbandaran Utama, PM No. 34 Tahun 2012, Berita Negara No.627 Tahun 2012.

Indonesia (4), Peraturan Menteri Perhubungan tentang Organisasi dan Tata Kerja Kantor Otoritas Pelabuhan Utama, PM No. 35 Tahun 2012, Berita Negara No.628 Tahun 2012.

Indonesia (5), Peraturan Menteri Perhubungan tentang Organisasi dan Tata Kerja Kantor Kesyahbandaran dan Otoritas Pelabuhan, PM No. 36 Tahun 2012, Berita Negara No.629 Tahun 2012.

Indonesia (6), Peraturan Menteri Perhubungan tentang Jenis, Struktur, dan Golongan Tarif Jasa Kepelabuhanan, PM No. 6 Tahun 2013, Berita Negara No.281 Tahun 2013. 